\title{
Galactagogue Effect of Euphorbia hirta (Euphorbiaceae) Aqueous Leaf Extract on Milk Production in Female Wistar Rats
}

\author{
Buno Koffi Koko, André Brou Konan, Flora Kouamé Amoin Kouacou, \\ Jules Marius Kacou Djétouan, Augustin Kouao Amonkan
}

Laboratoire de Nutrition et Pharmacologie, UFR-Biosciences, Université Félix HOUPHOUËT-BOIGNY, Abidjan, Côte d'Ivoire Email: ^akonanb@yahoo.fr

How to cite this paper: Koko, B.K., Konan, A.B., Kouacou, F.K.A., Djétouan, J.M.K. and Amonkan, A.K. (2019) Galactagogue Effect of Euphorbia hirta (Euphorbiaceae) Aqueous Leaf Extract on Milk Production in Female Wistar Rats. Journal of Biosciences and Medicines, 7, 51-65.

https://doi.org/10.4236/jbm.2019.79006

Received: July 24, 2019

Accepted: September 2, 2019

Published: September 5, 2019

Copyright $\odot 2019$ by author(s) and Scientific Research Publishing Inc. This work is licensed under the Creative Commons Attribution International License (CC BY 4.0).

http://creativecommons.org/licenses/by/4.0/

\begin{abstract}
Background: Populations of Gontougo (Côte d'Ivoire) commonly used $E u$ phorbia hirta (Euphorbiaceae) leaves as galactagogue to boost milk production in lactating women. Our study was carried to verify this traditional belief via evaluations of milk production, serum prolactin levels, body weight and mammary lobuloalveolar proliferation induced by the aqueous leaf extract of this medicinal plant in Wistar rats. Methods: 6 groups of 6 virgin rats and 6 groups of 6 lactating rats were used. Each lactating rat was isolated with its six pups. These groups of animals were treated orally with distilled water, Metoclopramide (Metocl $5 \mathrm{mg} / \mathrm{kg}$ ) and E. hirta aqueous leaf extract (EHae 100, 200,400 and $600 \mathrm{mg} / \mathrm{kg}$ ) daily during 17 days of lactation. The indirect method which assimilates the weight gain of untreated pups to the quantity of milk produced by lactating rats was used. At the end of the treatment, histological sections of the abdominal mammary glands of lactating rats were observed. Results: EHae administration induced an increase of milk production in lactating rats. This action of EHae was stronger at the dose of $200 \mathrm{mg} / \mathrm{kg}$. Milk production of the treated rats at a dose of $200 \mathrm{mg} / \mathrm{kg}$ was $118.14 \pm 1 \mathrm{~g}$. The quantity of milk produced by the control female rats was $83.83 \pm 0.88 \mathrm{~g}$. Compared with the control, EHae $200 \mathrm{mg} / \mathrm{kg}$ significantly increased milk production $(40.92 \%)(P<0.0001)$. EHae $200 \mathrm{mg} / \mathrm{kg}$ significantly increased the biosynthesis of prolactin $(\mathrm{PRL})$ in virgin rats $(P<0.0001)$. At this dose, PRL values measured at D7 and D14 were $26.44 \pm 8.64$ and $33.88 \pm 7.30$ $\mathrm{ng} / \mathrm{ml}$ respectively, whereas the value obtained in the controls that received distilled water was less than $0.5 \mathrm{ng} / \mathrm{ml}$. Histological analysis showed that EHae $200 \mathrm{mg} / \mathrm{kg}$ induced the development of the lobuloalveolar system of the mammary glands. Conclusion: EHae showed a galactagogue activity illustrated by increases of milk production, PRL secretions and the development
\end{abstract}


of the lobuloalveolar system of the mammary glands in treated female rats. This galactagogue property could partly justify the traditional use of this plant to boost milk production in lactating women.

\section{Keywords}

Euphorbia hirta, Metoclopramide, Galactagogue Effect, Prolactin, Milk Production

\section{Introduction}

The mortality of children under five is a real scourge in different parts of the world. Africa is severely affected by disturbing proportions in West and Central Africa. Three million children under the age of five die each year in these areas. This mortality is largely caused by child malnutrition [1]. Malnutrition can occur at different stages of a child's life. And often, it appears, unfortunately, at a very early stage, during the breastfeeding phase which is a crucial period in the development of the child. According to scientific knowledge, breastfeeding is the appropriate solution to this problem.

The positive impact of breastfeeding on the survival and health of the child is well established [2]. According to many studies, breastfeeding increases infant survival by at least six times. The risk of dying in the first six months is very low for well-fed infants. Infants exclusively breastfed are 14 times less likely to die in the first six months. Breastfeeding saves lives and promotes physical and mental health throughout childhood and beyond childhood [2] [3] [4] [5] [6] [7]. Exclusive breastfeeding reduces the incidence of many infectious diseases while lowering up to $30 \%$ hospitalizations due to infection during the first year of a child's life [8] [9]. It effectively participates in the prevention and control of bacterial meningitis, bacteremia, diarrhea, respiratory tract infections, otitis media and urinary tract infections in the newborn. In addition, breast milk is associated with better performance in intelligence tests and cognitive development. Breastfeeding improves intelligence from birth to adulthood [10]. It also reduces the risk of overweight, obesity and diabetes (type I and II) in children and later in adults [11]. In contrast, infants who receive little or no breast milk are likely to experience poorer health outcomes. Partially or non-breastfed children are 5 to 9 times more likely to become infected [2].

Also, WHO and UNICEF have jointly adopted exclusive breastfeeding as a global strategy to combat child mortality [12]. For this, the third Objective of Sustainable Development advocates working for the well-being and good health of mother and child. However, despite these multiple initiatives, it is found that the rate of exclusive breastfeeding worldwide is low [13]. Less than $37 \%$ of infants under 6 months of age are exclusively breastfed in developing countries [10]. This is the example of countries such as Chad, Niger, Burkina Faso and Côte d'Ivoire with respective proportions of $2 \%, 4 \%, 7 \%$ and $12 \%$ [12]. This 
finding makes breastfeeding a real public health problem on a global scale and more specifically in Africa with social and economic implications. There are still many constraints to its total adoption by populations. These include socioprofessional, cultural and/or aesthetic constraints [7] [14].

In developing countries and especially in rural areas where breast milk is the main infant food, hypogalactia remains the major constraint related to breastfeeding. Many mothers wanting to breastfeed their children are affected by this problem. They have low breast milk production [15]. These women cannot get the pharmacy products because of their high costs. In modern therapeutic, several medications have been used as galactagogues. Galactagogues are medications or substances to assist initiation, maintenance and augmentation of maternal milk production. Metoclopramide, domperidone, and the antipsychotics sulpiride and chlorpromazine are some galactagogues used in modern medicine [16]. They use medicinal plants to increase the production of breast milk. Previous works have shown the galactagogue activity of some plants including Leptadenia reticulate, Ipomoea digitata, Glycerrhiza glabra, Centella asciatica, Bacopa monnieri, Anethum sowa, fenugreek etc. [17]. Bako et al. [18] showed the galactagogue activity of Hibiscus sabdariffa (Malvaceae). The ethyl acetate fraction of the flowers significantly increases milk production and PRL synthesis. According to Datti et al. [19] and Lompo-Ouedraogo et al. [20], the leaves of Hippocratea obtusofolia (Alismataceae) and Acacia nilotica ssp adansonii (Fabaceae) would be capable of inducing galactagogue activities in guinea pigs and rats, respectively. The work of Gbadamosi and Okolosi [21] helped to safeguard traditional knowledge about the use of several galactagogue plants. In Côte d'Ivoire, $95 \%$ of women admit to having used galactogenic plants including $\mathrm{Eu}$ phorbia hirta (Euphorbiaceae) to induce milk production [22].

Many traditional medicinal practices commonly use Euphorbia hirta (Euphorbiaceae) to stimulate milk production in nursing mothers in Gontougo Region (Côte d'Ivoire). Gontougo located in the east is one of the very poor regions of Côte d'Ivoire.

Thus, the objective of this study was to verify the traditional belief regarding galactagogue property of $E$. hirta. This belief says that $E$. hirta increase milk production in lactating women. For this, the quantities of milk produced by lactating rats as well as weight gains of their pups were measured during 17 days. Histological sections of mammary glands of lactating females were observed. Serum PRL concentration was also measured in virgin females.

\section{Materials and Methods}

\subsection{Preparation of Euphorbia hirta Aqueous Extract}

Fresh leaves of Euphorbia hirta (Euphorbiaceae) were harvested in February 2016 in Béléouélé (village located five kilometers from the city of Tanda, Region of Gontougo, Côte d'Ivoire). The fresh leaves have been identified and authenticated by a Botany expert, Dr Emma AKE-ASSI of the "Centre National de Flo- 
ristique", UFR-Biosciences, Université Félix HOUPHOUËT-BOIGNY (Abidjan, Côte d'Ivoire). The plant extract was obtained according to the method used by Néné-Bi et al. [23]. The fresh leaves were washed and dried at room temperature $28^{\circ} \mathrm{C} \pm 2{ }^{\circ} \mathrm{C}$. Dried leaves were pulverized to powder with the use of a laboratory blender. $100 \mathrm{~g}$ of powder were macerated during $24 \mathrm{~h}$ in distilled water $(2 \mathrm{~L})$, thereafter filtered. Rotary evaporator (BUCHI, France) at temperature of $50^{\circ} \mathrm{C} \pm$ $5^{\circ} \mathrm{C}$ was used to concentrate the filtrate and Euphorbia hirta aqueous extract (EHae) obtained was re-dissolved extemporaneously in normal saline $(\mathrm{NaCl}$ $0.9 \%)$ for the experiment [24].

\subsection{Animals}

288 Wistar rats (Rattus norvegicus), including 36 virgin rats, 36 lactating rats and their 216 suckling pups. Each lactating rat was housed separately with its respective pups (6). All mature female rats used were 3 months old, weighed $180-220 \mathrm{~g}$ and were purchased from the Vivarium (Animal house) of Ecole Nationale Supérieure (ENS, Abidjan, Côte d'Ivoire). They were kept in temperature-controlled environment $\left(25^{\circ} \mathrm{C} \pm 2^{\circ} \mathrm{C}\right)$ with a $12 \mathrm{~h}$ light-dark cycle and were allowed free access to water and feed ad libitum throughout the acclimation period. Experimental procedures and protocols used in this study were approved by Ethical Committee of Health Sciences of Université Felix HOUPHOUËT-BOIGNY. These guidelines were in accordance with the European Council Legislation 87/607/EEC for the protection of experimental animals.

\subsection{Chemicals Used}

Metoclopramide (Metocl, Prokynil ${ }^{\circledR}$ ) was purchased from Laboratoires TECHNI-PHARMA, (France). All drugs (EHae and Metocl) were dissolved and/or diluted in distilled water on each day of our experiments [25] [26] [27] [28].

\subsection{Experimental Protocols}

\subsubsection{Measurement of Milk Production and Body Weight}

It was determined according to the method described by Sampson and Jansen [29]. Lactating rats were divided into 6 groups and were treated with different doses of test substances daily from D3 to D17. Each group was composed of six lactating rats. Group 1 served as normal control, while groups 2, 3, 4, 5 and 6 served as test animals and had received oral administration of drugs studied. Group 1 received distilled water. Group 2 received Metocl $5 \mathrm{mg} / \mathrm{kg}$. The other groups $(3,4,5,6)$ were treated with EHae at 100, 200, 400 and $600 \mathrm{mg} / \mathrm{kg}$ respectively. The substances were administered 12 hours before the pups weighing sessions, that is to say $18 \mathrm{~h} 00 \mathrm{~min}$ the day before. Pups were not treated but their weights were measured from D1 to D17 at different times of the day. At 07:00 am, the weight (P1) of the pups was determined after spending the previous night with lactating rats. Then they were immediately isolated from lac- 
tating rats for 4 hours. At 11:00 am, they are again weighed (P2) and returned to lactating rats for a one-hour breastfeeding period. The third weighing (P3) was determined at $12 \mathrm{~h} 00$ am for measuring the milk yield ingested by the pups. According to this method, the milk yield produced is given by the difference in weight of the pups before and after the feeding sessions. Weight gains are considered to be the milk yield ingested by the pups. However during each feeding session, it is noted use of ingested milk for the production of energy for respiration and movement of pups. This milk yield is therefore evaluated by the correlation coefficient of the weight loss. The milk yield measured is given by the following equation:

$$
\text { Milk yield }(\mathrm{g})=(P 3-P 2)+[(P 2-P 1) / 4]
$$

with

$(P 3-P 2)$ : Weight gain of the pups after lactating.

$(P 2-P 1) / 4$ : Correlation coefficient of the weight loss.

\subsubsection{Histological Study of Mammary Gland}

At J18 of post-partum, experimental lactating rats were anesthetized with ethyl urethane and sacrificed [30]. Then the upper abdominal pairs of the mammary glands were taken for histological study according to the standard method described by Bouagnon et al. [31] and Zougrou et al. [32]. Sections were taken from abdominal tissues, dehydrated in gradual ethanol, cleared in toluene and infiltrated in paraffin using automatic tissue processor. After routine processing, paraffin sections of each tissue were cut into $5 \mu \mathrm{m}$ thickness, stained with haematoxylin and eosin, and observed under light microscope.

\subsubsection{Evaluation of Serum PRL}

36 virgin rats were divided into 6 groups of 6 animals. Group 1 received distilled water. Group 2 received Metocl $5 \mathrm{mg} / \mathrm{kg}$. The other groups $(3,4,5,6)$ were treated with EHae at 100, 200, 400 and $600 \mathrm{mg} / \mathrm{kg}$ respectively. Drugs were administered daily to the animals in a single dose. At the days 0,7 and 14 of experimental period, animals were starved (16 hours), anaesthetized with ethyl urethane [30] [33]. Blood samples were collected from the animals through caudal puncture. Blood samples were centrifuged at $3000 \mathrm{rpm}$ for $10 \mathrm{~min}$ [34]. Serum was separated from the clot with pasteur pipette and dispensed into clean tube for the measurement of prolactin according to standard methods using the MiniVidas auto-analyser (Biomérieux, France). An immuno-enzymatic method was used for this purpose [35].

\subsection{Statistical Analysis}

All the data were expressed as Mean \pm Standard Error of Means (SEM). Statistical analyses were performed by one way analysis of variance (ANOVA) and differences between means were determined by Turkey's Multiple Comparison test using Graph Pad Prism 7.0 program (Microsoft, San Diego California, USA). A value of $P<0.05$ was considered significant. 


\section{Results}

\subsection{Milk Production}

Milk yields produced daily by the female rats before and after administration of the test substances were measured. The data revealed that milk yield produced by the rats in each experimental group were not proportional to the days of lactation (Figure 1). It has been observed periods of high and low increase of milk production. An increase of milk production was observed at intervals D4-D7 and D10-D14 when lactating rats were treated separately with Metocl $5 \mathrm{mg} / \mathrm{kg}$ and EHae. In contrast, a decrease production was observed at intervals D7-D10 and D14-D17.

Figure 2 shows the milk yields produced by the rats from D3 to D17. Metocl 5 $\mathrm{mg} / \mathrm{kg}$ induced a milk yield of $40.9 \pm 2.2 \mathrm{~g}$. With EHae, the most active dose was $200 \mathrm{mg} / \mathrm{kg}$. The rats receiving this dose produced $39.38 \pm 1.5 \mathrm{~g}$ of milk. This value is substantially equal to that obtained with Metocl $5 \mathrm{mg} / \mathrm{kg}(P>0.05)$. Compared with control rats $(28.05 \pm 0.57 \mathrm{~g})$, Metocl $5 \mathrm{mg} / \mathrm{kg}$ and EHae 200 $\mathrm{mg} / \mathrm{kg}$ induced highly significant increases of $45.78 \%(P<0.0001)$ and $40.36 \%(P$ $<0.0001)$. Quantities of $36.32 \pm 1.2 \mathrm{~g}$ and $34.12 \pm 1.3 \mathrm{~g}$ were obtained with EHae at 400 and $600 \mathrm{mg} / \mathrm{kg}$ respectively, corresponding to increases of $28.43 \%$ and 22.63\%. $28.1 \pm 1 \mathrm{~g}$ of milk were produced when EHae $100 \mathrm{mg} / \mathrm{kg}$ was used, an increase of $0.17 \%$. EHae at this low dose did not affect the production of milk in lactating rats $(P>0.05)$.

\subsection{Body Weight of Pups}

From day 1 of postpartum to day 17 of the experiment, the weights of the pups receiving exclusively breast milk were raised. On day 1 of the post partum, the weight of the six rats in the control group was estimated at $36.5 \pm 0.101 \mathrm{~g}$. Those of the pups whose mothers were treated with Metocl $5 \mathrm{mg} / \mathrm{kg}$ and the doses of EHae $(100 ; 200 ; 400 ; 600 \mathrm{mg} / \mathrm{kg})$ were $36.3 \pm 02 ; 35 \pm 3.1 ; 36 \pm 1.2 ; 34.7 \pm 0.38$ and $38.4 \pm 2.3 \mathrm{~g}$ respectively. Comparing the weight of pups of different groups showed no significant difference at post partum D1 $(P>0.05)$. At the end of the experiment, weights were $129.2 \pm 2.3 \mathrm{~g}$ and $127.7 \pm 1.4 \mathrm{~g}$ respectively for pups whose mothers had received Metocl $5 \mathrm{mg} / \mathrm{kg}$ and EHae $200 \mathrm{mg} / \mathrm{kg}$. These two recorded values were greater than that of the pups whose mothers had been treated with distilled water (control). The weight of these pups was 107.79 \pm 0.8 g. Metocl $5 \mathrm{mg} / \mathrm{kg}$ and EHae $200 \mathrm{mg} / \mathrm{kg}$ promoted very significant growth of pups $(P<0.0001)$. These two doses induced respective increases of $19.86 \%$ and $18.47 \%$ (Figure 3).

\subsection{Histology of Mammary Tissue}

The galactagogue activity induced by EHae could also be due to the ability of the extract to promote the development of lobuloalveolar system. To test this hypothesis, histological sections were performed on samples from mammary glands of lactating rats that were treated daily with the test substances (Figure 4). 
Analysis of the histological sections obtained revealed that the EHae $200 \mathrm{mg} / \mathrm{kg}$ had an interesting effect on the measured parameter. At $200 \mathrm{mg} / \mathrm{kg}$, EHae caused an increase of the number of cells within the lobules as compared to the lobuloalveolar system of the control rats.

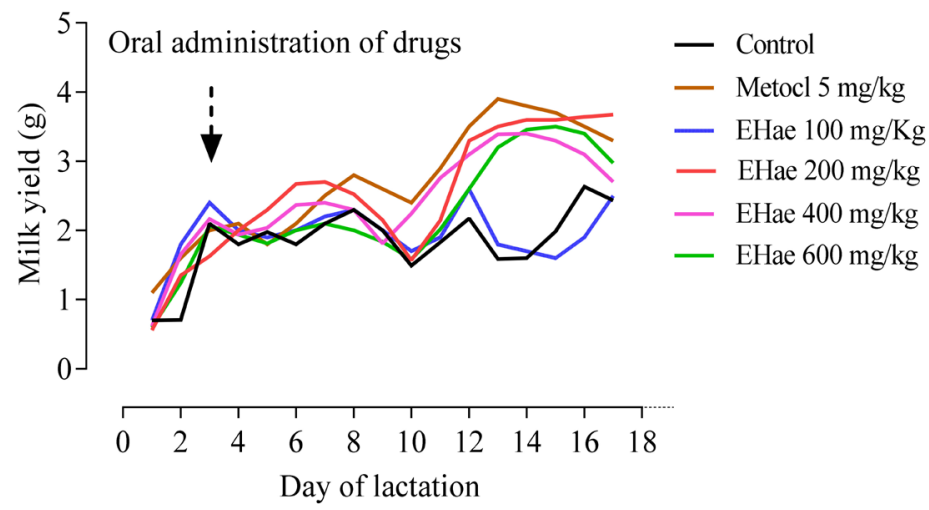

Figure 1. Effect of EHae on milk production. Mean \pm S.E.M, $n=6$, EHae: Euphorbia hirta aqueous extract, Metocl: Metoclopramide.

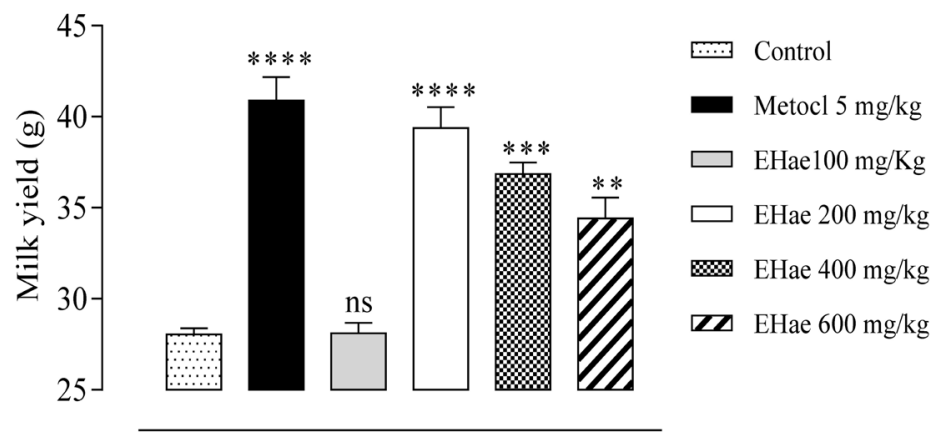

Figure 2. Effect of EHae on the milk quantity in female rats from D3 to D17 of lactation. Mean \pm S.E.M, $\mathrm{n}=6$, Test drugs: significant from normal control: $\mathrm{ns} \mathrm{P}>0.05,{ }^{*} \mathrm{P}<0.05,{ }^{* *} \mathrm{P}<0.01,{ }^{* * *} \mathrm{P}<0.001,{ }^{* * *} \mathrm{P}<$ 0.0001, EHae: Euphorbia hirta aqueous extract, Metocl: Metoclopramide.

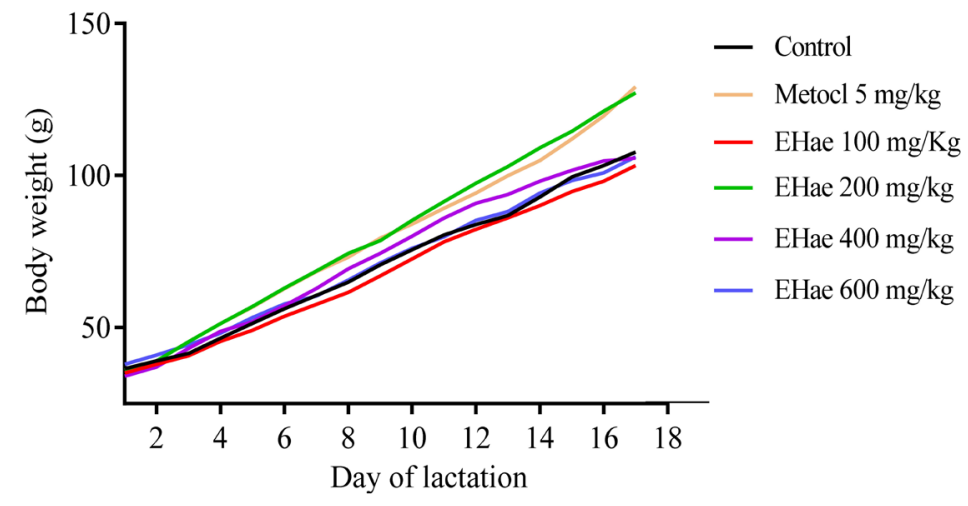

Figure 3. Evolution of the weight of pups receiving the milk of female rats treated with EHae. Mean \pm S.E.M, $n=6$, EHae: Euphorbia hirta aqueous extract, Metocl: Metoclopramide. 


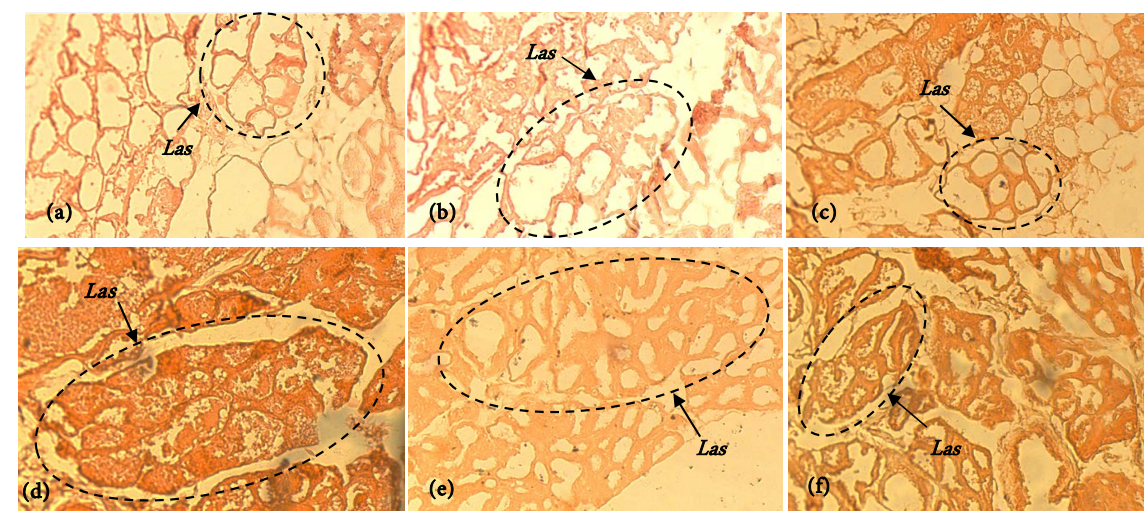

Figure 4. Histological sections of the mammary glands of lactating rats treated with EHae. (a) Control, (b) Metocl $5 \mathrm{mg} / \mathrm{kg}$, (c) EHae $100 \mathrm{mg} / \mathrm{kg}$, (d) EHae $200 \mathrm{mg} / \mathrm{kg}$, (e) EHae $400 \mathrm{mg} / \mathrm{kg}$, (f) EHae $600 \mathrm{mg} / \mathrm{kg}$. A proliferation of alveolar cells was induced with EHae $200 \mathrm{mg} / \mathrm{kg}$. Las: lobuloalveolar system, EHae: Euphorbia hirta aqueous extract, Metocl: Metoclopramide, $\mathrm{H} \& \mathrm{E} \times 400$.

\subsection{Serum PRL Release}

In order to justify the galactagogue effect induced by $E$. hirta, virgin female rats were treated with Metocl $5 \mathrm{mg} / \mathrm{kg}$ and EHae $(100 ; 200 ; 400 ; 600 \mathrm{mg} / \mathrm{kg}$ ) for 14 days.PRL assays were performed on D0, D7 and D14. At D0, all administered substances were not able to cause PRL release greater than $0.5 \mathrm{ng} / \mathrm{ml}$ (Table 1). At day 7, only EHae $200 \mathrm{mg} / \mathrm{kg}$ induced a highly significant increase in PRL secretion estimated at $26.44 \pm 28.64 \mathrm{ng} / \mathrm{ml}$ compared with less than $0.5 \mathrm{ng} / \mathrm{ml}$ for the control group $(P<0.0001)$. On day 14, PRL secretions induced by Metocl 5 $\mathrm{mg} / \mathrm{kg}$ and EHae $200 \mathrm{mg} / \mathrm{kg}$ were substantially equal $(P>0.05)$. In fact, Metocl 5 $\mathrm{mg} / \mathrm{kg}$ caused a PRL secretion of $32.33 \pm 9.13 \mathrm{ng} / \mathrm{ml}$ whereas that of EHae 200 $\mathrm{mg} / \mathrm{kg}$ was $33.88 \pm 7.30 \mathrm{ng} / \mathrm{ml}$.

\section{Discussion}

Measuring the milk yield produced by a rat is usually very difficult. However, according to Lompo-Ouedraogo et al. [20], it is possible to estimate this quantity of milk produced by carrying out different sessions of weighing of the pups. This method considers the pups as powerful vacuum cleaners capable of completely emptying the contents of the mammary glands. It is commonly used to evaluate the galactagogue property of vegetable products [29]. In this study, different test substances were administered daily to lactating rats. Comparison of milk yields produced by the treated rats with that of the control group showed that Metocl 5 $\mathrm{mg} / \mathrm{kg}$ and aqueous extract $(200 \mathrm{mg} / \mathrm{kg})$ increased milk production. These increases, highly significant $(P<0.0001)$, were $45.78 \%$ and $40.36 \%$ respectively. The results are similar to those of Hosseinzadeh et al. [36] obtained with 500 $\mathrm{mg} / \mathrm{kg}$ of Nigella sativa (Ranunculaceae) seeds extract. Metocl $5 \mathrm{mg} / \mathrm{kg}$, EHae $200 \mathrm{mg} / \mathrm{kg}$ and ethanolic extract of $N$. sativa seeds $(1000 \mathrm{mg} / \mathrm{kg})$ would have had substantially the same effects on breast milk production in female rats. Indeed, Metocl $5 \mathrm{mg} / \mathrm{kg}$ and EHae $200 \mathrm{mg} / \mathrm{kg}$ increased milk production of $45.78 \%$ and 
Table 1. Effects of EHae on plasma PRL concentration.

\begin{tabular}{ccccccc}
\hline & \multicolumn{7}{c}{ PRL concentrations induced by treatments (ng/ml) } \\
\hline $\begin{array}{c}\text { Study } \\
\text { period }\end{array}$ & Control & $\begin{array}{c}\text { Metocl } \\
5 \mathrm{mg} / \mathrm{kg}\end{array}$ & $\begin{array}{c}\mathrm{EHae} \\
100 \mathrm{mg} / \mathrm{kg}\end{array}$ & $\begin{array}{c}\mathrm{EHae} \\
200 \mathrm{mg} / \mathrm{kg}\end{array}$ & $\begin{array}{c}\mathrm{EHae} \\
400 \mathrm{mg} / \mathrm{kg}\end{array}$ & $\begin{array}{c}\mathrm{EHae} \\
600 \mathrm{mg} / \mathrm{kg}\end{array}$ \\
\hline Day 0 & $<0.5$ & $<0.5$ & $<0.5$ & $<0.5$ & $<0.5$ & $<0.5$ \\
Day 7 & $<0.5$ & $<0.5$ & $2.53 \pm 2.94$ & $26.44 \pm 8.64$ & $5.00 \pm 0.52$ & $32.33 \pm 9.13$ \\
Day 14 & $<0.5$ & $32.33 \pm 9.13$ & $6.02 \pm 1.33$ & $33.88 \pm 7.30$ & $10.95 \pm 8.29$ & $5.08 \pm 1.22$
\end{tabular}

Mean \pm S.E.M, $n=6$ (experiments), EHae: Euphorbia hirta aqueous extract, Metocl: Metoclopramide, PRL: Prolactin,.

$40.36 \%$ respectively. While the increase in milk production induced by the ethanolic extract of $N$. sativa seeds $(500 \mathrm{mg} / \mathrm{kg})$ was estimated at $37 \%$. The galactagogue effects induced by plant species can be explained by their composition of bioactive substances capable of increasing the biosynthesis of milk [18]. Bioactive substances suspected to be at the origin of the galactagogue activity of medicinal plants are flavonoids, tannins, saponins and alkaloids. Gaya et al. [37] have shown that flavonoids, tannins, saponins and alkaloids are the major causes of galactagogue activity of Hibiscus sabdariffa (Malvaceae) leaves. These phytochemicals would be recognized dopamine antagonists by many authors. Dopamine is a competitive antagonist of PRL. Thus, an inhibition of dopamine synthesis by bioactive substances would lead to an increase of milk synthesis [38]. The differences in effects observed between doses of EHae (100; 200; 400 and $600 \mathrm{mg} / \mathrm{kg}$ ) would be explained by a variation of the quantity of bioactive molecules responsible of the galactagogue activity contained in each dose. These bioactive compounds present in the E. hirta leaves have been identified [39] [40] [41] [42].

Analysis of milk production versus days of lactation showed that the milk yield produced by the rats of each experimental group was not proportional to the days of lactation. The same observations were made during the evaluation of the galactagogue activity of the leaves of Musa x paradisiaca (Musaceae) in the rat [43]. The non-linearity of milk production versus days of lactation is explained by the fact that the mammary glands undergo an alternation of proliferation and apoptosis of mammary cells during lactation [44]. Therefore, there is a variation in the kinetics of milk biosynthesis depending on the period of lactation. The cell proliferation rate being greater than the rate of apoptosis in early lactation, there has been an increase in milk production from D1 to D7 of lactation for all rats. After the peak of milk production observed at D7 of lactation, the equilibrium was reversed, that is to say, the rate of apoptosis becomes higher than the rate of proliferation of mammary cells. This had the effect of reducing milk production from D7 to D10 of lactation for almost all experimental groups. During the experiment, the pups gained weight. This body weight increase of the pups would be exclusively dependent on the quantity and quality of the milk 
produced by the lactating rats. This is in agreement with Hamed et al. [45]. These authors note that weight gains of the pups are indicators of milk production in female rats. The highly significant growths $(19.86 \%$ and $18.47 \%)$ of the pups receiving milk from female rats treated with Metocl $5 \mathrm{mg} / \mathrm{kg}$ and EHae 200 $\mathrm{mg} / \mathrm{kg}$, respectively, would militate in favor of galactagogue activity of these two substances.

In order to identify the mechanism of induced galactagogue activity, serum PRL assays were performed after treatment of virgin rats at D0, D7, and D14 of the experiment. The results revealed that at D0, none of the substances administered was able to elicit a PRL secretion greater than $0.5 \mathrm{ng} / \mathrm{ml}$. This result is comparable to that obtained by Simelane et al. [46] after 10 days of experimentation. According to the authors, all doses of Gunnera perpensa (Gunneraceae) aqueous extract and Metocl $5 \mathrm{mg} / \mathrm{kg}$ induced PRL secretion estimate at 0.6 $\mathrm{ng} / \mathrm{ml}$. At D7, only AHae $200 \mathrm{mg} / \mathrm{kg}$ dose differentiated itself from all other substances administered. It induced a PRL secretion estimated at $26.44 \pm 8.64$ $\mathrm{ng} / \mathrm{ml}$. It induced a highly significant increase $(P<0.0001)$ compared to that obtained in the controls (less than $0.5 \mathrm{ng} / \mathrm{ml}$ ). At D14, only Metocl $5 \mathrm{mg} / \mathrm{kg}$ resulted in a secretion substantially equal to that of EHae $200 \mathrm{mg} / \mathrm{kg}$. Metocl 5 $\mathrm{mg} / \mathrm{kg}$ caused a PRL secretion of $32.33 \pm 9.13 \mathrm{ng} / \mathrm{ml}$ when that of EHae 200 $\mathrm{mg} / \mathrm{kg}$ was $33.88 \pm 7.30 \mathrm{ng} / \mathrm{ml}$. However, there is no significant difference between these two values $(P>0.05)$. These results are similar to those of previous works comparing the effects of plant extracts and Metocl on milk secretion in female rats. According to Bako et al. [18], doses of 200 and $400 \mathrm{mg} / \mathrm{kg}$ of the ethylacetate fraction of $H$. sabdariffa favored a highly significant PRL secretion of $31.45 \pm 2.39$ and $34.03 \pm 1.67 \mathrm{ng} / \mathrm{ml}$ respectively at D15 of post partum in lactating rats. Metocl $5 \mathrm{mg} / \mathrm{kg}$ induced a PRL secretion of $26.40 \pm 0.94 \mathrm{ng} / \mathrm{ml}$. The roots of Triumfetta rhomboidea L. (Tiliaceae) also caused a very significant secretion of prolactin in lactating rats [47]. The increased of PRL secretion induced by leaves of E. hirta as those caused by other plants would be related to the galactagogue activity of this plant. After parturition, the initiation and maintenance of milk production are mainly controlled by continuous PRL secretion [48]. PRL increases the proliferation of receptors on the surface of alveolar cells. It promotes the entry of water and nutrients into alveolar cells for the synthesis of milk [49] [50].

The galactagogue activity induced by $E$. hirta leaves could also be explained by the ability of the extract to promote development of the lobuloalveolar system. In order to verify this hypothesis, histological sections were performed from mammary gland samples of lactating rats treated with different doses of the aqueous extract of $E$. hirta (EHae). Analysis of histological sections of mammary glands of controls and treated rats revealed that only EHae $200 \mathrm{mg} / \mathrm{kg}$ induced a development of the lobuloalveolar system. These results are in agreement with those of previous works. Gunnera perpensa aqueous extract employed at 1600 $\mathrm{mg} / \mathrm{kg}$ also induced development of mammary alveolar cell whereas $\mathrm{NaCl}$ and 
Metocl $5 \mathrm{mg} / \mathrm{kg}$ had no effect on the development of mammary glands [46]. The aqueous extract of Acacia nilotica ssp adansonii (Mimosaceae) stimulates the development and differentiation of the lobuloalveolar system [20]. During lactation, mammary glands undergo an alternation of proliferation and apoptosis of mammary alveolar cells [44]. Moreover, consumption of plants rich in antioxidants such as flavonoids and phenolic compounds may have some beneficial effect on slowing the aging of mammary alveolar cells [51]. This would have the advantage of increasing the number of alveolar cells and the production of milk [20].

\section{Conclusion}

In conclusion, the aqueous extract of Euphorbia hirta (Euphorbiceae) leaves showed a galactagogue activity in female rats. Euphorbia hirta aqueous extract induced an increase of milk production and prolactin secretion. This property could be attributed to the substances contained in this plant aqueous extract. These substances would promote a slowing of programmed death of mammary alveolar cells. These results could militate in favor of its use by the Gontougo populations to increase milk production in lactating women. However, in view of the safe and efficient use of this medicinal plant, it would be interesting to carry out further studies. These works will include the evaluation of the effects of aqueous leaf extract on the growth, hematological and biochemical parameters of pups and lactating rats.

\section{Acknowledgements}

The authors are grateful to Dr Emma AKE-ASSI of the Centre National de floristique (Université Felix Houphouet-Boigny, Abidjan, Côte d'Ivoire) for botanical identification of Euphorbia hirta (Euphorbiaceae).

\section{Author's Contributions}

All authors contributed equally in the study. They made substantial contributions to the design of the study, the collection of the data as well as the preparation and analysis of the data. They also drafted the manuscript and gave final approval for its submission to the journal for consideration of publication.

\section{Consent}

It is not applicable.

\section{Conflicts of Interest}

The authors declare that there is no conflict of interest that could be perceived as prejudicing the impartiality of the research reported. Also, this research did not receive any specific grant from any funding agency in the public, commercial, or not-for-profit sector. It was funded by personal efforts of the authors. 


\section{References}

[1] Sokol, E., Aguayo, V.M. and Clark, D. (2007) Protéger l'allaitement maternel en Afrique de l'Ouest et du Centre. 25 années d'application du Code International sur la Commercialisation des Substituts du Lait Maternel. UNICEF, Bureau Régional pour l'Afrique de l'Ouest et du Centre, 40 p. (In French) https://www.unicef.org/wcaro/WCARO_Pub_Breastfeeding-fr.pdf

[2] Sankar, M.J., Sinha, B., Chowdhury, R., Bhandari, N., Taneja, S., Martines, J. and Bahl, R. (2015) Optimal Breastfeeding Practices and Infant and Child Mortality: A Systematic Review and Meta-Analysis. Acta Paediatrica, 104, 3-13. https://doi.org/10.1111/apa.13147

[3] Peres, K.G., Cascaes, A.M., Nascimento, G.G. and Victora, C.G. (2015) Effect of Breastfeeding on Malocclusions: A Systematic Review and Meta-Analysis. Acta Paediatrica, 104, 54-61. https://doi.org/10.1111/apa.13103

[4] Lodge, C.J., Tan, D.J., Lau, M.X.Z., Dai, X., Tham, R., Lowe, A.J., Bowatte, G., Allen, K.J. and Dharmage, S.C. (2015) Breastfeeding and Asthma and Allergies: A Systematic Review and Meta-Analysis. Acta Paediatrica, 104, 38-53.

https://doi.org/10.1111/apa.13132

[5] Horta, B.L., de Mola, C.L. and Victora, C.G. (2015) Long-Term Consequences of Breastfeeding on Cholesterol, Obesity, Systolic Blood Pressure and Type 2 Diabetes: A Systematic Review and Meta-Analysis. Acta Paediatrica, 104, 30-37. https://doi.org/10.1111/apa.13133

[6] Horta, B.L., de Mola, C.L. and Victora, C.G. (2015) Breastfeeding and Intelligence: A Systematic Review and Meta-Analysis. Acta Paediatrica, 104, 14-19.

https://doi.org/10.1111/apa.13139

[7] Khatun, H., Comins, C.A., Shah, R., Islam, M.M., Choudhury, N. and Ahmed, T. (2018) Uncovering the Barriers to Exclusive Breastfeeding for Mothers Living in Dhaka's Slums: A Mixed Method Study. International Breastfeeding Journal, 13, 44. https://doi.org/10.1186/s13006-018-0186-5

[8] Heinig, M.J. (2001) Host Defense Benefits of Breastfeeding for the Infant. Effect of Breastfeeding Duration and Exclusivity. Pediatric Clinics of North America, 48, 105-123. https://doi.org/10.1016/S0031-3955(05)70288-1

[9] Pound, C.M., Unger, S.L., Canadian Paediatric Society, Nutrition and Gastroenterology Committee and Hospital Paediatrics Section (2012) The Baby-Friendly Initiative: Protecting, Promoting and Supporting Breastfeeding. Paediatrics Child Health, 17, 317-321. https://doi.org/10.1093/pch/17.6.317

[10] Victora, C.G., Horta, B.L., de Mola C.L., Quevedo, L., Pinheiro, R.T., Gigante, D.P., Gonçalves, H. and Barros, F.C. (2015) Association between Breastfeeding and Intelligence, Educational Attainment, and Income at 30 Years of Age: A Prospective Birth Cohort Study from Brazil. The Lancet Global Health, 3, e199-e205. https://doi.org/10.1016/S2214-109X(15)70002-1

[11] Doukouré, M., Bayala. B., Guenné, S., Tindano, B. and Belemtougri, R. (2018) Phytochemical Composition, Toxicity, Antioxidant and Lactogenic Activities of $\mathrm{Eu}$ phorbia hirta (L.). International Journal of Advanced Research, 6, 322-335. https://doi.org/10.21474/IJAR01/7524

[12] UNICEF (2010) A Good Departure in the Life. 20 p. (In French) http://www.unicef.lu

[13] WHO (2009) Infant and Young Child Feeding Model Chapter for Textbooks for Medical Student and Allied Health Professionals. 99 p. 
[14] Cai, X., Wardlaw, T. and Brown, D.W. (2012) Global Trends in Exclusive Breastfeeding. International Breastfeed Journal, 7, 12. https://doi.org/10.1186/1746-4358-7-12

[15] Sultana, A., Rahman, K.U. and Manjula, S.M. (2013) Clinical Update and Treatment of Lactation Insufficiency. Medical Journal of Islamic World Academy of Sciences, 21, 19-28. https://doi.org/10.12816/0000207

[16] Garg, R. and Gupta, V.B. (2010) A Comparative Study on Galactogogue Property of Milk and Aqueous Decoction of Asparagus racemosus in Rats. International Journal of Pharmacognosy and Phytochemical Research, 2, 36-39.

[17] Gabay, M.P. (2002) Galactogogues: Medications That Induce Lactation. Journal of Human Lactation, 18, 274-279. https://doi.org/10.1177/089033440201800311

[18] Bako, I.G., Abubakar, M.S., Mabrouk, M.A. and Mohammed, A. (2014) Lactogenic Study of the Effect of Ethyl-Acetate Fraction of Hibiscus sabdariffa Linn (Malvaceae) Seed on Serum Prolactin Level in Lactating Albino Rats. Advance Journal of Food Science and Technology, 6, 292-296. https://doi.org/10.19026/ajfst.6.26

[19] Datti, Y., Idris, M.M. and Mudi, S.Y. (2014) Effect of Hppocratea obtusifolia Extracts on Lactation Induciment. Bayero Journal of Pure and Applied Sciences, 7, 131-134. https://doi.org/10.4314/bajopas.v7i1.24

[20] Lompo-Ouedraogo, Z., van der Heide, D., van der Beek, E.M., Swarts, H.J., Mattheij, J.A. and Sawadogo, L. (2004) Effect of Aqueous Extract of Acacia nilotica ssp adansonii on Milk Production and Prolactin Release in the Rat. Journal of Endocrinology, 182, 257-266. https://doi.org/10.1677/joe.0.1820257

[21] Gbadamosi, I.T. and Okolosi, O. (2013) Botanical Galactogogues: Nutritional Values and Therapeutic Potentials. Journal of Applied Biosciences, 61, 4460-4469. https://doi.org/10.4314/jab.v61i0.85594

[22] Adepo, Y.P., Dally, T. and Amonkan, K.A. (2016) Ethnobotanical Surveys of Plants Lactogens Properties of the African Pharmacopoeia (Ivory Coast): Study of the Biotolerance in Wistar Rats. International Journal of Science and Research, 5, 1274-1279. https://doi.org/10.21275/v5i7.11071601

[23] Nene-Bi, S.A., Traoré, F., Zahoui, O.S. and Soro, T.Y. (2008) Phytochemical Composition, Pharmacological and Toxicological Studies of an Aqueous Extract of Bridelia ferruginea benth. (Euphorbiaceae) in Mammalians. Afrique Science, 4, 287-305. (In French) https://doi.org/10.4314/afsci.v4i2.61690

[24] Konan, A.B., Amonkan, A.K., Ahui, M.L.B., Bouafou, K.G.M., Kouakou, L.K., Kpahé, F.Z. and Datté, J.Y. (2011) Myostimulating Effects of Sesamum radiatum Aqueous Leaf Extract in Isolated Guinea Pig Taenia caeci Contractile Activity. African Journal of Traditional, Complementary and Alternative Medicine, 8, 377-385. https://doi.org/10.4314/ajtcam.v8i4.6

[25] Chiwororo, W.D.H. and Ojewole, J.A.O. (2009) Spasmolytic Effect of Psidium guajava Linn. (Myrtaceae) Leaf Aqueous Extract on Rat Isolated Uterine Horns. Journal of Smooth Muscle Research, 45, 31-38. https://doi.org/10.1540/jsmr.45.31

[26] Konan, A.B., Ahui, M.L.B., Saraka, A.I., Amonkan, A.K., Kouakou, K.L., Bléyéré, M.N. and Datté, J.Y. (2014) In Vitro Effects of Hydroethanolic Extract from Roots Bark of Parquetina nigrescens (Periplocaceae) on Rabbit Duodenum Contractile Activity. World Journal of Pharmaceutical Research, 3, 139-150.

[27] Konan, A.B., Bouafou, K.G.M., Kouakou, L.K., Bléyéré, M.N., Amonkan, A.K., Zannou-Tchoko, J.V., Ahui, M.L.B. and Datté, J.Y. (2012) Effects of Sesamum radiatum Aqueous Leaf Extract on Rhythmic Contractions of Uterine Smooth Muscle 
Bundles from Pregnant Rats. International Journal of Life Science and Medical Research, 2, 82-89. https://doi.org/10.5963/LSMR0204005

[28] Ahui, M.L.B., Konan, A.B., Zannou-Tchoko, J.V., Amonkan, A.K., Kati-Coulibaly, S. and Offoumou, M.A. (2013) Identification of Gingerols in Ginger (Zingiber officinale Roscoe) by High Performance Liquid Chromatography-Tandem Mass Spectrometry and Pharmacologic Studies of Its Aqueous Extract on the Rabbit Isolated Duodenum Contractility. Journal of Physiology and Pharmacology Advances, 3, 16-26. https://doi.org/10.5455/jppa.20130228065221

[29] Sampson, D.A. and Jansen, G.R. (1984) Measurement of Milk Yield in Lactating Rat from Pup Weight and Weight Gain. Journal of Pediatric Gastroenterology and Nutrition, 3, 613-617. https://doi.org/10.1097/00005176-198409000-00023

[30] Amoikon, K.E., Kouamé, K.G. and Kati-Coulibaly, S. (2012) Effect of Chromium and Proteins Diets in Rats. International Journal of Plant, Animal and Environnemental Sciences, 2, 1-8.

[31] Bouagnon, R., Yéo, D., Kouassi, K., Beugre, K., Djaman, J.A. and N'guessan, J.D. (2015) Hepatoprotective Effect of Aqueous Extract of Lippia multiflora Leaves against Ethanol-Induced Toxicity in Wistar Rats. European Journal of Medicinal Plants, 7, 146-155. https://doi.org/10.9734/EJMP/2015/16394

[32] Zougrou, N.E., Blahi, A.N., Kouassi, K.D. and Kouakou, K. (2018) Effects of the Aqueous Extract of Cnestis Ferruginea on the Histological Structure of Female Rat Ovary and Uterine Horns. Biomédical Journal Scientific and Technical Research, 2, 2073-2078. https://doi.org/10.26717/BJSTR.2017.01.000625

[33] Méité, A., Kouamé, K.G., Kati-Coulibaly, S. and Offoumou, A.M. (2008) Etude de la valeur nutritionnelle du pain normal et des pains composites contenant de la farine de graine de Citrillus lanatus (Cucurbitacées). Bulletin de la Société Royale des Sciences de Liège, 77, 80-103.

[34] Amoikon, K.E., Kouamé, K.G. and Offoumou, A.M. (2010) Effets du chrome sur la croissance, la biométrie des organes et la valeur moyenne des métabolites sériques des rats recevant une administration orale de vitamines. Bioterre, Revue Internationale des Sciences de la Terre, 10, 26-37.

[35] Wild, D.G. (2013) The Immunoassay Handbook. 4th Edition, Elsevier Science, Amsterdam, $1036 \mathrm{p}$.

[36] Hosseinzadeh, H., Tafaghodi, M., Mosavi, M.J. and Taghiabadi, E. (2013) Effect of Aqueous and Ethanolic Extracts of Nigella sativa Seeds on Milk Production in Rats. Journal of Acupuncture and Meridian Studies, 6, 18-23. https://doi.org/10.1016/j.jams.2012.07.019

[37] Gaya, I., Mohammad, O., Suleiman, A., Maje, M. and Adekunle, A. (2008) Toxicological and Lactogenic Studies on the Seeds of Hibiscus sabdariffa Linn (Malvaceae) Extract on Serum Prolactin Levels of Albino Wistar Rats. The Internet Journal of Endocrinology, 5, 1-6. https://doi.org/10.5580/26b5

[38] Okasha, M.A.M., Abubakar, M.S. and Bako, I.G. (2008) Study of the Effect Aqueous Hibiscus sabdariffa L. Seed Extract on Serum Prolactin Level in Lactating Albino Rats. European Journal of Scientific Research, 22, 575-583.

[39] Kumar, S., Malhotra, R. and Kumar, D. (2010) Euphorbia hirta: Its Chemistry, Traditional and Medicinal Uses, and Pharmacological Activities. Pharmacognosy Review, 4, 58-61. https://doi.org/10.4103/0973-7847.65327

[40] Huang, L., Chen, S. and Yang, M. (2012) Euphorbia hirta (Feiyangcao): A Review on Its Ethnopharmacology, Phytochemistry and Pharmacology. Journal of Medicinal Plants Research, 6, 5176-5185. https://doi.org/10.5897/JMPR12.206 
[41] Asha, S., Deevika, B. and Mohamad, S.A. (2014) Euphorbia hirta Linn: A Review on Traditional Uses, Phytochemistry and Pharmacology. World Journal of Pharmaceutical Research, 3, 180-205.

[42] Olounladé, A.P., Azando, E.V.B., Tchétan, E., Hounzangbé-Adoté, M.S. and Attakpa, Y.E. (2017) A Review of the Ethnomedical Uses, Phytochemistry and Pharmacology of the Euphorbia Genus. The Pharma Innovation Journal, 6, 34-39.

[43] Mahmood, A., Omar, M.N. and Ngah, N. (2012) Galactagogue Effects of Musa X paradisiaca Flower Extract on Lactating Rats. Asian Pacific Journal of Tropical Medicine, 5, 882-886. https://doi.org/10.1016/S1995-7645(12)60164-3

[44] Wiart-Letort, S., Chedly, H.B. and Boutinaud, M. (2013) Le turnover des cellules dans la glande mammaire évalué par immunohistochimie, comme indicateur de la production de lait. Revue Française d'Histotechnologie, 26, 77-87.

[45] Hamed, R.S., Breakaa, M.A. and El Said, H. (2015) Effect of Acacia nilotica Leaves Extract and Flaxseed Oil Supplementation on Milk Yield and Reproductive Performance of Rabbit Does. Egyptian Poultry Science Journal, 35, 627-646.

[46] Simelane, M.B.C., Lawal, O.A., Djarova, T.G., Musabayane, C.T., Singh, M. and Opoku, A.R. (2012) Lactogenic Activity of Rats Stimulated by Gunnera perpensa L. (Gunneraceae) from South Africa. African Journal of Traditional, Complementary and Alternative Medicine, 9, 561-573. https://doi.org/10.4314/ajtcam.v9i4.14

[47] Sahoo, H.B., Mandal, P.K., Sagar, R. and Bhattamisra, S.K. (2016) Evaluation of Lactogenic Activity of Triumfetta rhomboidea L. Root: Validating Its Traditional Usage. Journal of Experimental and Integrative Medicine, 6, 26-30. https://doi.org/10.5455/jeim.160216.or.146

[48] Neville, M.C., Morton, J. and Umemura, S. (2001) Lactogenesis: The Transition from Pregnancy to Lactation. Pediatrics Clinics of North America, 48, 35-52. https://doi.org/10.1016/S0031-3955(05)70284-4

[49] Matsuzaki, T., Machida, N., Tajika, Y., Ablimit, A., Suzuki, T., Aoki, T., Hagiwara, H. and Takata, K. (2005) Expression and Immunolocalization of Water-Channel Aquaporins in the Rat and Mouse Mammary Gland. Histochemistry and Cell Biology, 123, 501-512. https://doi.org/10.1007/s00418-005-0753-x

[50] Hua, Y., Jiang, W., Zhang, W., Shen, Q., Chen, M. and Zhu, X. (2013) Expression and Significance of Aquaporins during Pregnancy. Frontiers in Bioscience, 18, 1373-1383. https://doi.org/10.2741/4186

[51] Jalili, C., Salahshoor, M.R., Yousefi, D., Khazaei, M., Darehdori, A.S. and Mokhtari, T. (2015) Morphometric and Hormonal Study of the Effect of Urtica diocia Extract on Mammary Glands in Rats. International Journal of Morphology, 33, 983-987. https://doi.org/10.4067/S0717-95022015000300028 